\section{JCL}

Journal of the College of Languages

Open Free Access, Peer Reviewed Research Journal

Est.1994

\section{http://jcolang.uobaghdad.edu.iq}

\section{P-ISSN: 2074-9279 \\ E-ISSN: 2520-3517 \\ 2022, No.(45) \\ Pg.1-25}

\title{
Ideological Polarization as a Deception Strategy in the Discourse of American Think Tanks: A Critical Discourse Analysis
}

\author{
Ali Hamzah Lafta MA. Candidate
}

E-mail: ali.hamza501@gmail.com

\section{Prof. Sabah S. Mustafa (Ph.D.)}

E-mail: sabahmustafa1956@gmail.com

University of Baghdad, College of Languages, Department of English Language, Baghdad, Iraq.

( Received on 12/10/2021 - Accepted on 10/11/2021 - Published on 2/1/2022 )

https://doi.org/10.36586/jcl.2.2022.0.45.0001

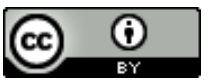

This work is licensed under a Creative Commons Attribution 4.0 International License.

\begin{abstract}
Deception is an inseparable facet of political discourse in attaining strategic political gains though compromising public opinion. However, the employment of discursive deception strategies by the policy-making institutions of think tanks has not received due attention in the literature. The current study aims at exploring how the ideologizing deception strategies are utilized by the conservative American think tank of the Washington Institute to reproduce socio-political realities and re-shape public opinion. To fulfill this task, van Dijk's (2000) notion of ideological polarization which shows positive self-representation and negative other representation is adopted to conduct a critical discourse analysis of four Arabic texts released with the main focus on four different political topics. Results reveal the centrality of employing deception strategies for the sake of realizing political wins for
\end{abstract}


establishing an ideological hegemony while simultaneously polarizing an $U s$ against Them extreme.

Key words: Critical discourse analysis, deception, ideological polarization, political discourse, think tanks

\section{Introduction}

Deception is a communicative process initiated by the intention to lead recipients to harbor false information (Galasinski, 2000, pp. 19-20). Many deceptive apparatuses have become part and parcel of achieving social as well as political wins. In the realm of political discourses and to practice a better control of the way people cognize reality, politicians utilize discursive strategies of deception and the institutions of think tanks represent one of the richest political discourses in this respect. According to McGann (2019, p. 13), a think tank is a research center that draws on academic methodologies to provide support for policy makers through political analyses to arrive at better public policies. The products of think tanks take a number of forms such as research and policy briefs, extensive studies, political reports, commentaries, and articles. Think tanks employ a wide array of techniques and strategies to influence the debates of particular policies. Yet, the scope of the think tanks' independence and objectivity should be the subject matter of critical analyses that tackle the 'scientific' work and public image of think tanks as most of which refrain from disclosing verifiable funding and finance information (Plehwe, 2015, p. 359). Thus, and with the reputation of being scientific, most of the think tanks' products pass unchallenged (Wiarda, 2010, p. 31). One of the institutional models of these policy-making entities is advocacy think tanks (henceforth ATTs) which support and promote conservative ideologies. According to Weaver (1989, p. 567), ATTs "combine a strong policy, partisan or ideological bent with aggressive salesmanship and an effort to influence current policy debates." A good example about the political impact of ATTs is the influence of the Cato Institute and the Heritage Foundation during the pre-war stage against Iraq and the way they successfully fed the American mainstream media platforms and the White House convincing them that Iraq possessed and was planning to launch attacks using Weapons of Mass Destruction (Paolucci, 2009, p. 879). 
The present study aims at pinpointing and explicating the discursively wrought deception strategies in the discourse of the conservative American think tank of The Washington Institute based on a CDA model for unveiling the underlying encoded ideologies. To this end, four Arabic texts produced by The Washington Institute are analyzed in terms of (a) the ideologically polarized positive self-description and negative otherdescription, and (b) the way reality is altered so the recipients are led to (re)weigh their perception towards social and political realities.

\section{Literature review}

Critical Discourse Analysis (CDA)

Critical discourse analysis CDA is an interdisciplinary research field that seeks to deconstruct the way language is employed to produce and perpetuate social practices which then might give rise to structural social change (Flowerdew and Richardson, 2018, p. 1). Writers and speakers manifest unconscious linguistic reflections of their social and political affiliations through which particular ideologies and prejudices surface which thus make a writer a discourse reproducer (Fowler et al., 1979, pp. 185-186).

According to Wodak (1997, p. 173), CDA mainly tackles unlimited breadth of social interactive communication which ultimately retains a linguistic materialization analyzed against its social contextual containers. In this respect, Fairclough (1989, p. 1) simply avers that the political and social power relations are shaped, re-introduced, and naturalized because of its linguistic-rooted behaviour. Thus, textual analysis that is based on a theoretical foundation is considered an effective tool by which the inextricably context-dependent ideological meanings are rooted out, explained, and, ideally, deconstructed to its molecular components of sociopolitical power (Fowler et al., 1979, p. 168). Taken this into account, discourse critical theory must have the theoretical and applied potential to elucidate any ideological realizations construed as naturalized common sense in order to identify the ways through which the public is affected by the characteristics of the discursive social effects (Fairclough, 1995, p. 28). Therefore, the one common endeavor all CDA analysts share is the attempt to bring about a better human well-being, decrease peoples' suffering (Fairclough, 2012, p. 10), and establish a reaction to discursively wrought social and/or political problems which crystalize as everyday social practices 
(Chouliaraki and Fairclough, 1999, p. 60). Van Dijk (2015, p. 8) quite justifiably assumes that power manifests itself in the discursive mediation between the abstract macro-level social structures such as social groupings or political institutions and the more concrete micro-level of written or spoken discourses such as grammar rules and lexicon.

\section{Deception}

Deception is an untrue belief communicated to purposefully convince recipients otherwise through falsification where falsity is one of its main defining characteristics (Galasinski 2000, pp. 19-20). Deception is also conceptualized in the pragmatics of Grice, i.e., a deceptive act is defined as the intentional flouting of one or all of the four maxims (quality, quantity, manner, relevance) which necessarily entails violating Grice's Cooperative Principle according to which people cooperate to communicate meaningfully (Oswald et al., 2016, p. 509).

Lying and manipulation are reduced to be either a facet under the greater umbrella of deception, or simply an equally perceived synonymous with deception. However, Strudler (2005, p. 458) differentiates between manipulation (process) and deception (product) stating that the product eventually arises as a result of self-defense motivations which render it an act of inherently defensive nature. This sort of distinction can be traced to political discourses since the final goal of deceivers revolves around cornering their rivals to conceive a false reality which ultimately serves a deceiver to persuade the recipients to embark on doing things that the former finds beneficial (Macdonald, 2007, p. 83). Anna van't Veer (2014, p. 244) believes that lying is another extension of deception, and even if liars are socially disfavored yet researchers report that deception is in fact common. For Mahon (2014, p. 246), the act of deceiving people is significantly different from that of lying to them. The former stipulates achieving a successful outcome in that deceivers are not successful unless they have satisfied the condition of fulfilling a tangible result, whereas the latter does not require such a stipulation, i.e., liars may well still be described as liars even if they do not obtain a particular result where lies are still be considered lies even when the recipients do not interact with it.

Deception can also be the way deceivers conceal information which pushes the recipients to develop false beliefs while they momentarily cease 
to have true information (Gupta, 2014, p. 250). However, Mahon (2014, p. 247) goes further to suggest that both the concealment and withholding true information are utilized to ensure that the recipients remain ignorant of the truth behind what is spoken or written. But he contends that these two acts still differ from deception. Concealment occurs when people embed or decipher a truth while withholding information is to totally refrain from mentioning the smallest clue about that truth. Carter (2014, p. 266) explains that deception takes various shapes in politics (e.g. political speeches), doctors-patients interactions (e.g. drug abuse denial, case of malingering), academic contexts (e.g. plagiarism) as research shows there is more interest in the deconstruction and analysis of deception of discourse that result in high communicative costs than those discourses of everyday communication. Political deception is of multifarious realizations in political discourses.

For a successful political deception, deceivers always have a ready a well-plotted cover story (Godson and Wirtz, 2010, p. 427). In everyday political discourses, the meanings of words are stretched thin so that new content is loaded into them. In order to (re)create novel meanings, political actors draw on two levels, (a) a political action theme, and (b) a political linguistic content that actualizes those political themes (Dunmire, 2012, p. 737). In this vein, Edelman (1988) asserts that realities which describe a particular political circumstance is an exclusive result of the political language needed at that political moment (cited in Dunmire 2012, p. 737). Thus, for Edelman, a political reality is contingent upon the extent to which meanings are bent and not only on objectively verifiable facts. This may well produce more acceptable realities that are discursively structured by the political participants of a particular society (Teubert, 2010, p. 15). However, the crux of the matter lies in the way a political actor brings to existence entities that have not existed before (e.g. anti-climate change or pro-abortion narratives) and re-introduce them as a naturalized set of socio-political entities (Chilton, 2004, p. 49).

\section{Previous studies}

A number of studies on strategies of discursive deception have drawn on a CDA approach as well as pragmatic models of analysis to explicate the way political discourses employ deception strategies. Bhatia (2006) tackles texts of press conferences held between the Chinese President Zemin and the 
United States President Bush and singles out the three findings of (a) positivity to enhance mutual respect and trust, (b) persuasion techniques for more political influence, and (c) techniques of evasion to critical questions of the media utilized by the two presidents to embed ideological disagreements. Al-Hindawi and Al-Aadili (2017) investigate the American presidential electoral speeches of the then presidential candidates in the U.S. concluding that the candidates employ pragmatic strategies of deception such as speech acts and violations of Grice's maxims to achieve their political gains. ElZawawy (2017) examines the application of a Criteria-based Content Analysis to expose political lying in electoral campaigns as a part of the speeches of the then American presidential candidates Hilary Clinton and Donald Trump. El-Zawawy comes to the conclusion such numeric-based models of analysis pay no attention to the essential role of context and thus is not sensitive to any contextual variability and consequently are not suitable to categorize discourses as deceptive or non-deceptive. Olajimbiti (2019) follows a multimodal CDA analysis to deconstruct deception in Facebook post where 250 sampled posts and narrowed down to 50 posts as the most politically deceptive during the general election in Nigerian in 2019. Olajimbiti concludes that the deceptive content targeted Facebook users to drive them towards particular politicians and affect their elector opinion.

Although a recognizable amount of research has explored deception in political discourse, the present study examines the discursive deception strategies at the argumentative as well as the rhetorical levels so as to contribute to the current literature with a more focused detection of manufacturing deception in think tanks.

\section{Methodology}

This study follows a model of analysis that draws on van Dijk's (2000) Ideology and Discourse. The overarching critical theme is van Dijk's 'ideological square', i.e., foreground/background our good/bad qualities and foreground/background their bad/good qualities (van Dijk, 1998, 2000, 2006). The qualitative aspect is satisfied though the argumentative and rhetorical levels of analysis tackling the deployment of deception strategies. The quantitative aspect of analyzing the deception strategies is addressed through a frequency plus percentage accounts.

At the argumentative level, Generalization is the strategy that enables writers to cloud unsupported arguments with a more generalized 
language to render the message more appealing and persuasive which in turn reflect well ideological social attitudes towards particular issues. The use of this strategy can be semantically tracked in quantifiers such 'many', 'most', 'all', and also time expression such as 'constantly' and 'regularly' (van Dijk, 2000, pp. 71-72). Examples is a strategy that provides space for bringing to the discussion real life examples which further solidifies and details what is supposed to be a representative example of a particular state of affairs in order to stir up imagination and memorization of the propositions being made (van Dijk, 2000, pp. 69-70). This strategy serves to polarize doers of 'good deeds' against those who commit 'bad deeds in two opposite ideological extremes. However, presenting examples runs a great risk of being merely exceptional cases and thus inapplicable to fulfill a safe generalization. Fallacies, according to van Eemeren (2009, pp. 1-2), are flawed argumentative claims that motivate groundless arguments. Fallacies materialize when the logical relations that link conclusions to its premises are manipulated for the sake of producing a particular false argument (van Dijk, 2000, p. 71). Even if the premises are claims that may well hold verifiable truth, fallacious arguments typically bring together these valid premises to substantiate e.g. a disfavored policy through presenting vague and/or unrelated premises to arrive at favorable set of conclusions (van Dijk, 2000, p. 58).

The rhetorical strategies of euphemisms, metaphors, and hyperboles are deployed to foreground or background particular socio-political attributes and positions (van Dijk, 2000, pp. 58-9). A metaphor is an expression that is established through the cognitive substitutability of similar concert or abstract qualities between two unrelated things (Nate, 2006, p. 511) to further enhance what originally are less understandable or unfamiliar meanings in order to render them more comprehensible (van Dijk, 2000, p. 77). In consequence, recipients resort to analogical resemblance and embrace perceptions directed towards a particular social or political situation which paves the way to communicating more ideological messages. Euphemism arises when a particular expression is mitigated through altering the semantic content of words and phrases so as to avoid committing oneself to directly express negativity towards others. This allows speakers to convey ideological messages without sparking negative impressions, a technique that also serves the positive Us-introduction and negative Other-introduction (van 
Dijk, 2000, pp. 68-9). Hyperboles are semantically characterized rhetorical strategies used to reinforce the meaning of particular claims. The hyperbolic expressions such as 'greatly', 'extremely', 'deeply', 'the worst' etc. are exaggerative devices deployed to deliver a stronger message and are typical ways to make set up a self-positive presentation and a negative-other presentation (van Dijk, 2000, p. 73).

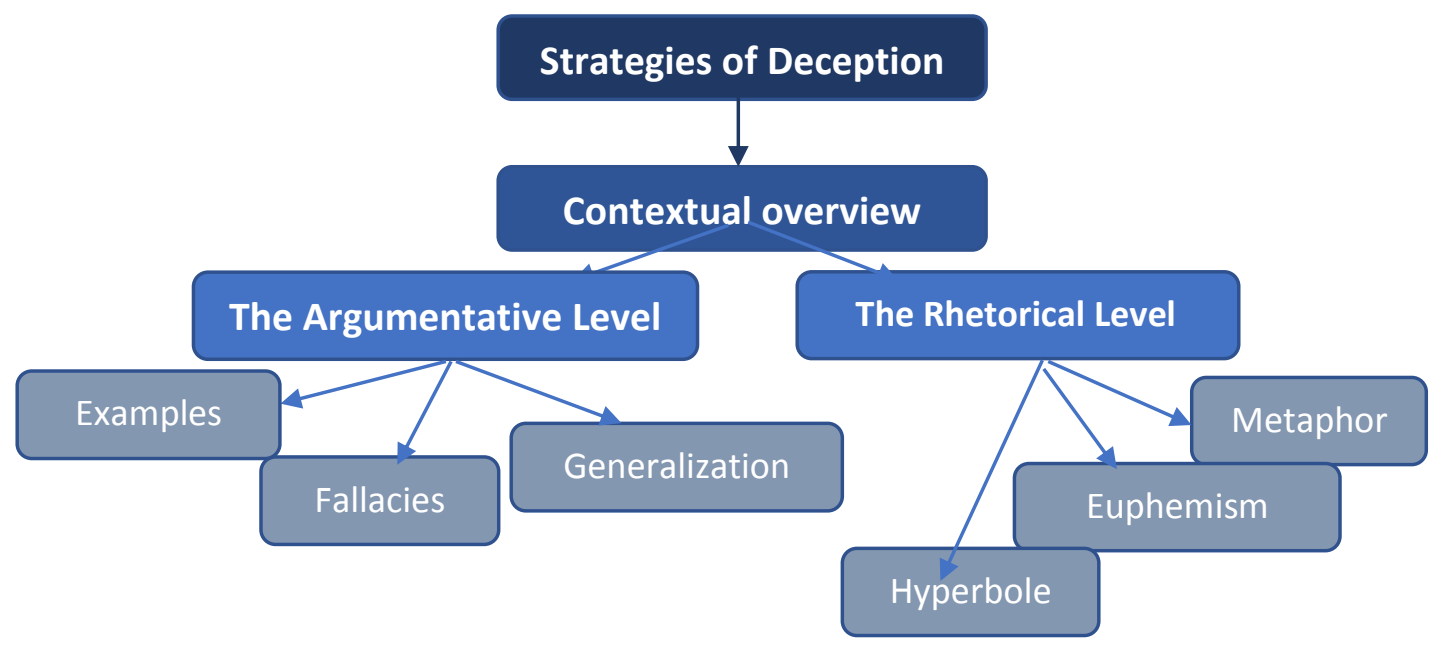

Figure (1) the adopted model of analysis

\section{Data description}

The selected corpus is four written texts that fall under the genre of political discourse. The texts are originally written in Arabic by Arab writers whose analytical role in The Washington Institute include contributing to the Arabic content of political analysis. The texts cover the period from 2017 to 2020 and are of various lengths in terms of number of words and are retrieved from the official website of The Washington Institute. The data selection criteria are (a) texts must be a written textual content published by one of the Arab writers at The Washington Institute, and (b) they must address one of the four political topics of (a) the Islamic terrorism, (b) the Russian influence in the Middle East, (c) the Israeli-Palestinian conflict, and (c) the U.S. policy in the Middle East. Each topic is represented by one text, hence a total of four texts. The following table illustrates the selected corpus of texts. 
Table (1): The corpus of analysis

\begin{tabular}{llllll}
\hline Political theme & $\begin{array}{l}\text { No. } \\
\text { of } \\
\text { texts }\end{array}$ & $\begin{array}{l}\text { No. of } \\
\text { words }\end{array}$ & $\begin{array}{l}\text { Publication } \\
\text { year }\end{array}$ & Text type \\
\hline Islamic terrorism & 1 & 1,026 & 2017 & $\begin{array}{l}\text { Brief } \\
\text { analysis }\end{array}$ \\
The Russian Influence in the Mid. East & 1 & 1,249 & 2019 & $\begin{array}{l}\text { Brief } \\
\text { analysis }\end{array}$ \\
The Israeli-Palestinian conflict & 1 & 1,098 & 2020 & $\begin{array}{l}\text { Article } \\
\text { (testimony) }\end{array}$ \\
The U.S. policies in the Middle East & 1 & 532 & 2017 & $\begin{array}{l}\text { Article } \\
\text { (testimony) }\end{array}$ \\
\hline Total & & & & \\
\hline
\end{tabular}

\section{Results and discussion}

The statistics below reflect the quantitative aspect of the deception strategies in the data analyzed and thus in the discourse of the Washington Institute. However, these numbers are not intended to provide comparisons between the different strategies to materialize the four political topics since such a task lies beyond the scope of the present study. The corpus analyzed indicates a relatively moderate-to-high frequency of deceptive strategies. The Islamic terrorism is reproduced through the highest total of (44) argumentative and rhetorical strategies, while the Russian influence in the Middle East is re-introduced through the second highest frequency of (28) strategies. The Washington Institute utilized as many as (24) strategies to remold The Israeli-Palestinians conflict. Finally, the U.S. policy in the Middle East is reproduced through (21) strategies. The following illustration 
provides an overview of the numbers of the deployed deception strategies in the light of the four political topics.

Table 2: Distribution of deception strategies per political topic

\begin{tabular}{lllll}
\hline Deception & Islamic & The & The & The U.S. \\
strategies & terrorism & Russian & Israeli- & Policy in \\
& & Influence & Palestinian & the Mid. \\
& in the & Conflict & East \\
& Mid. & \\
& East & \\
& &
\end{tabular}

\section{The Argumentative Level}

Generalization

Examples

Fallacies

\section{4}

11

$\begin{array}{ll}4 & 1 \\ 5 & 3 \\ 11 & 3\end{array}$

2

1

5
5

3

5

\section{The Rhetorical Level}

\begin{tabular}{lllll} 
Euphemism & 17 & 10 & 6 & 4 \\
Metaphor & 2 & 7 & 3 & 4 \\
Hyperbole & 5 & 4 & 6 & 0 \\
\hline Total & 44 & 28 & 24 & 21 \\
\hline
\end{tabular}

As illustrated in figure (2) below, the most frequent strategy at the argumentative level is fallacies (48\%) that the Washington Institute deploys to manufacture its preferred version of the political topic of Islamic terrorism. This can be attributed to the powerful argumentative potential of fallacious arguments where seemingly valid premisses are presented as the best interpretation of the issue at hand. Thus, lay recipients are invited to induce the simplest conclusion: Islam is in fact violent at its core nature.

The strategy of examples (42\%) is the second highest utilized deception strategy at this level. Its highly functional argumentative validity makes it quite practical to complement the strategy of fallacies and push the recipients towards unequivocally accepting, and thus reducing, the examples introduced to be micro-level manifestations of alleged inherent violent of the 
Islamic faith, hence the falsely-wrought social and political reality of Islam is successfully realized.

Generalization (42\%) is also the second most used deception strategy that is employed at this level to recast the U.S. policy in the Middle East. The high abundancy of this strategy reflects a discursive dynamism in terms of (a) a polarized (re)production of the socio-political image of the Middle East, and (b) the reinforcement of already-existed false beliefs towards this region and its inhabitants.

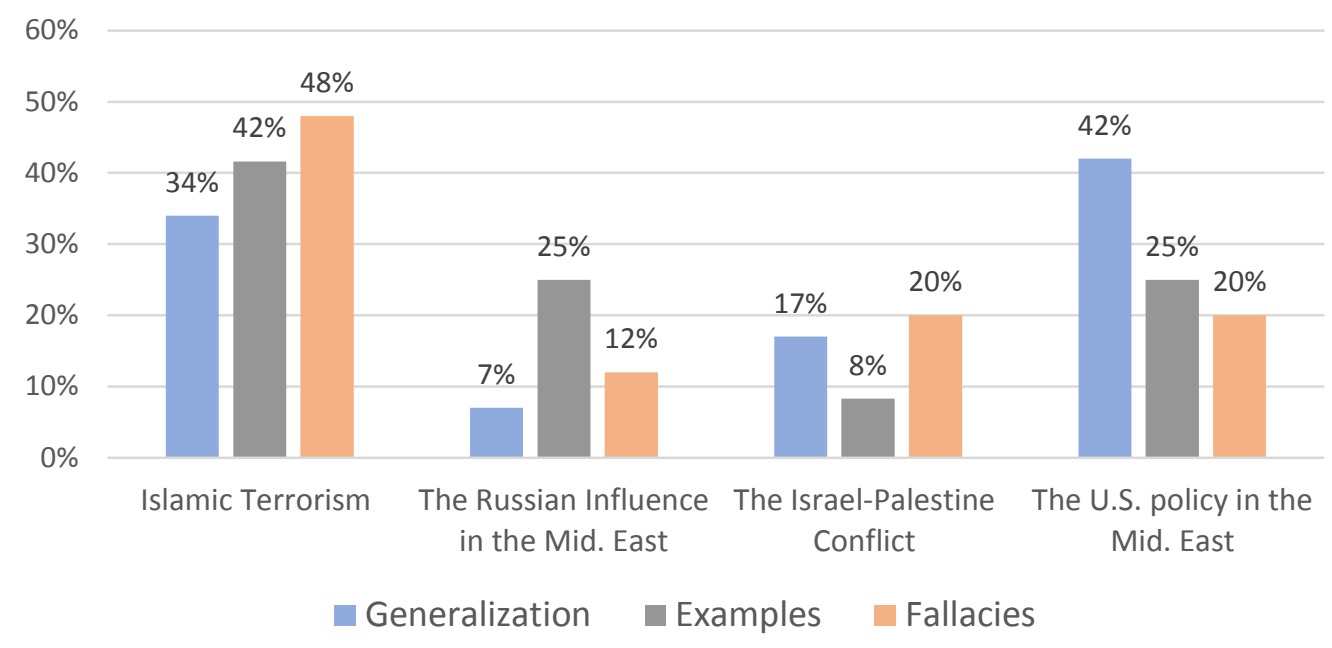

Figure (2) Frequency and Percentage of deception strategies at the Argumentative Level

At the rhetorical level, the highest frequency of the strategy of euphemism (48\%) occurs in the realization of the political topic of Islamic terrorism. The Washington Institute draws heavily on euphemized lexical items that seem a more palatable discursive apparatus to communicate ideologized anti-Islam conservative content.

The Russian role in the Middle East has the most application of metaphors (42\%) which may well be indicative of the Washington Institute's attempt to employ indirect yet cognitively sustainable discursive ways to establish a positive self-presentation against a negative other-presentation. 
The strategy of hyperbole (40\%) is most observable in reproducing the Israeli-Palestinian conflict. This indicates that hyperbolic propositions serve to increase the highly recurrent theme in the discourse of the Washington Institute towards Palestinians as the ones who hinder the peacebuilding process and deny the Israelis' right to exist. The result is a more legitimized geo-political re-introduction of Israel.

Figure (3) shows the frequencies and percentages detected at the rhetorical level.

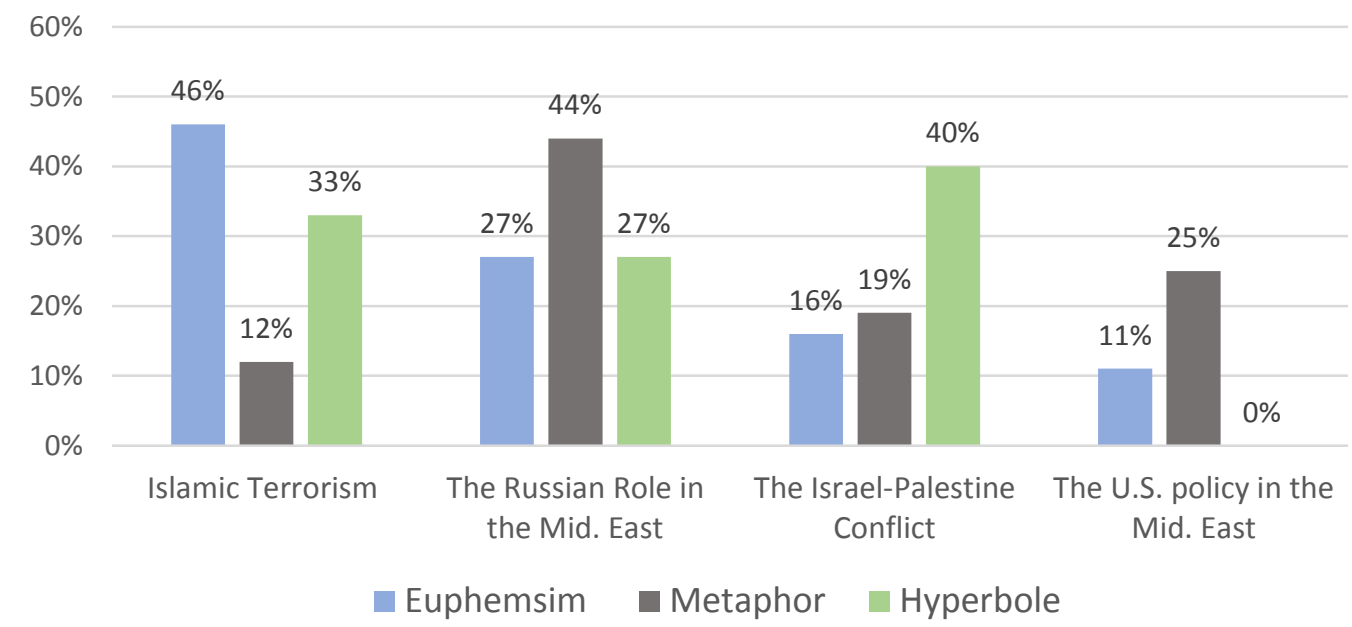

Figure (3) Frequency and Percentage of the Rhetorical Level

\section{Contextual Overview}

The four political topics selected are a reflection of the conservative ideological implicit and explicit embeddedness observed in the discourse of The Washington Institute. The topic of Islamic Terrorism is an attempt to reintroduce Islam as an inherently violent and thus a flawed faith. The Russian role in the Middle East marks the endeavor of the Institute to reproduce the image of Russia as a negative contributor of the peace-building efforts in this region of the world. The Israeli-Palestinian conflict is reproduced so as to lend Israel more international legitimacy and dismiss the Palestinians as the ones who hold no sincere intention to bring peace to the region. The U.S. policy in the Middle East is reduced to the actions taken by the Obama administration whose political efforts are represented as detrimental to the 
Arab leaders while re-presenting Israel as a friendlier and more legitimate regional partner.

The Argumentative Level

1. Generalization

Exc. 1

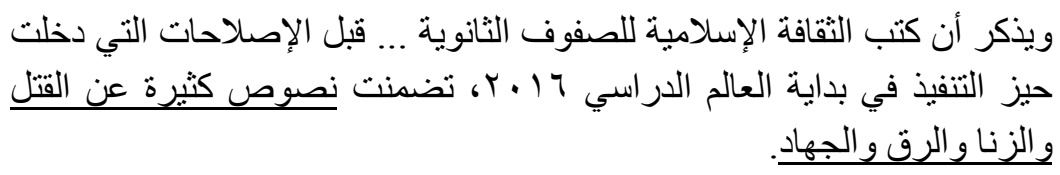

(The Washington Institute, 2017)

Before 'الإصلاحات', i.e., 'reforms' find their way to the textbooks of Islamic education, many references were made to killing, adultery, slavery, and jihad (The Washington Institute, 2017). As informing as it may look, the claim in this excerpt is intended to be acceptable and thus believable due to a generalized narrative of the way Islam is reflected in the education of high schools in the Arab countries. The 'نصوص كثيرة', i.e., 'many texts' is employed to generalize the essence of the Islamic faith and hence a normalizing re-presentation of Islam is communicated. That is, the qualifier 'many' at least sets a framed understating at two levels, (a) it functions to further re-invoke and thus magnify the already-existing false comprehension of the nature of the Islamic teachings in terms of e.g. killing non-Muslims and slavery, and (b) as it develops a broad description, it facilitates a more unequivocal acceptance of Islam as a flawed religion as, the generalization goes, there is even no need to mention how 'many' terrorism-motivating 'texts' reside within the faith of Islam. The deceptive reproduction of Islam lies in the Institute's attempt to convey that the evidence is in fact too many texts in the Muslims' most sacred book, i.e., the holy Quran, where the Institute implies that it is completely unnecessary to take the discussion-of how Islam motivates terrorism - any further.

Exc. 2

$$
\begin{aligned}
& \text { كما أفادت بعض التقارير أن عدداً كبيراً من المسؤولين العرب التقوا سراً مع } \\
& \text { رئيس الوزراء الإسر ائيلي بنيامين نتنياهو ومسؤولي الدفاع في حكومته. وتفيد العيد }
\end{aligned}
$$




$$
\text { التقارير أن إسرائيل تستسيغ التعاون الأمني والاستخباري الوثيق مع ... عدة }
$$

دول خليجية. (The Washington Institute, 2017)

The Washington Institute (2017) deploys the strategy of presenting a broader description of an allegedly shared political destiny of the Israelis and the Arabs in order to re-naturalize the geopolitical dimension and hence the very existence of Israel. The generalized proposition is initiated with ' عدداً كبير ا من 'a 'a المسؤولين العرب', i.e., 'a great number of Arab officials' to set the narrative tone of reemphasizing that all Arab leaders realize that their best political route to stay in power is through a publicly announced recognition of the state of Israel followed by a full economic and political normalization. While 'a great number' loosely invokes a false impression in lay recipients that there indeed is what may well make prime minister Netanyahu and the of Arab leaders come to terms, the generalization in this excerpt still retains a powerful deceptive potential, i.e., it brings about the impression that at least most of the Arab leaders, if not all of them, are eager to seek more normalized relations with the Israel which in turn shadows the Palestinians' cause to seek an independent state while it foregrounds Israel's geopolitical legitimacy.

\section{Examples}

Exc. 3

كما تناولت [ الكاتبة دلال سلامة ] نص آخر في كتاب الثقافة الإسلامية للصف

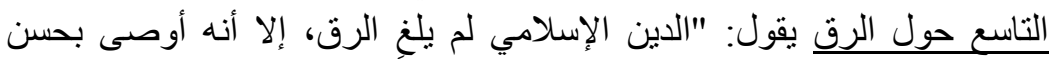

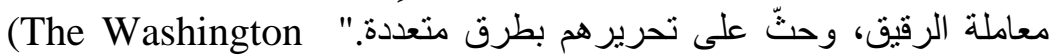

Institute, 2017)

Bringing to the discussion supposedly revealing examples is a strategy that helps The Washington Institute (2017) to exemplify a tangible proof about a preferred version of the nature of Islam. In this excerpt, an article by the Jordanian writer Dalal Salama is mentioned as an example of the religious terrorism literature which is said to be frequently found the religion textbooks of primary and middle schools. Salama's article selects a specific facet of Islamic terrorism, it is a 'نص اخر', i.e., 'another text' in the religion textbook of the $9^{\text {th }}$ grade which talks about slavery in Islam. While the Washington Institute is not concerned with challenging the philosophy of 
slavery in Islam, the message it attempts to reproduce is the very fact that such an Islamic discourse simply exists in primary and secondary education. The message goes on to reemphasize that the mere existence of such narratives exposes the true essence of this religion, i.e., an ethically flawed religion that, up to this day, permits making people slaves and controlling their freedom. Thus, it is Them, Muslims and Islam, who seek slavery even in the current more modern and civilized time, and it is Us, the West, who hold the right to fight such a religious terrorism.

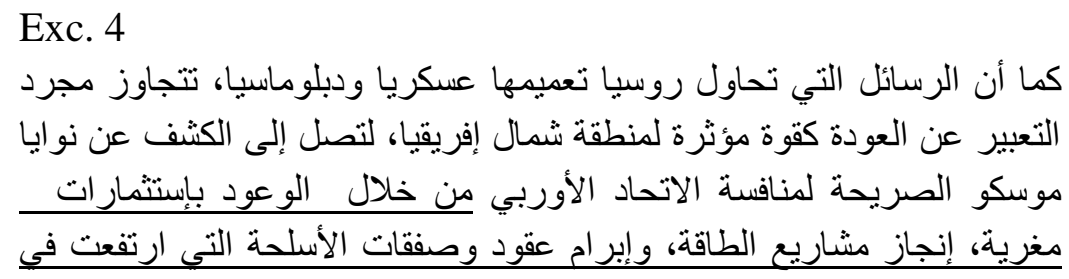

الفترة الأخيرة. (The Washington Institute, 2019)

In North Africa, Russia makes the best of pretending to commit itself to economically attractive investments, building energy projects, and weaponry agreements (The Washington Institute, 2019). Although such levels of relations may well be mutually beneficial and thus politically valid among countries, yet the Institute re-deploys it as another example of ' نوايا موسكو الصريحة', i.e., 'Moscow's true intentions'. The example is initiated through the phrase 'من خلال' and it is then detailed into three parts of 'إستثمار مغرات مغرية', 'إبرام عقود وصفقات الاسلحة', and 'إنجاز مشاريع طاقة', i.e., 'attractive investments', 'energy projects achievements', 'striking contracts and bargains' respectively. The Institute conveys that Russia's 'intentions' are in fact recognizable and therefore must not be mistaken as simply diplomatically motivated, i.e., regardless of what Moscow publicly asserts, the Washington Institute re-interprets those intentions as well-planned attempts to control the region of North Africa. Thus, the Russians are re-positioned in the negative light of being manipulators whose only goal is the full control of North region of Africa.

\section{Fallacies}

Exc. 5 


\section{ولكن بعيداً عن هذه الميّزة [اتفاق التطبيع الاخير] على المدى القريب للفلسطينيين، أظهر التاريخ أن الدول العربية التي تجمعها علافات مع إسرائيل}

(The Washington هي أكثر فاعلية في النهوض بالمصالح الفلسطينية.

Institute, 2020)

The Arab states which have agreed to normalize relations with Israel are effectively more positioned to defend the 'المصالح الفلسطينية', i.e., 'the interests of Palestine' (The Washington Institute, 2020). The central premise of this argument is that normalization is the sole solution the Palestinians and Arabs should consider. The phrase 'أظهر التأريخ', i.e., 'history shows' commences

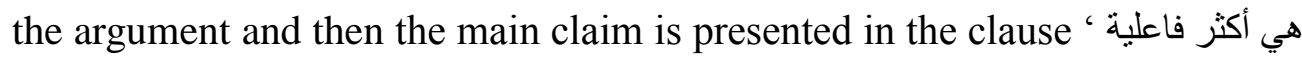
في النهوض بالمصالح الفلسطينية of Palestine'. While The Washington Institute (2020) calls for normalized relations with the Israelis, which entails a full recognition of the State of Israel, the falsity lies in the justification suggested, i.e., if Arabs agree to recognize the state of Israel and officially normalize relations with it, following other Arab countries, then they will have the privilege of being 'أكثر فاعلية', i.e., 'more effective' when attempts to settle down the IsraeliPalestinian conflict are made. This is a flawed justification as it runs the risk of marginalizing the very core of the conflict: the Israelis practice their socalled right to exist on the Palestinian soil against the will of the Palestinians.

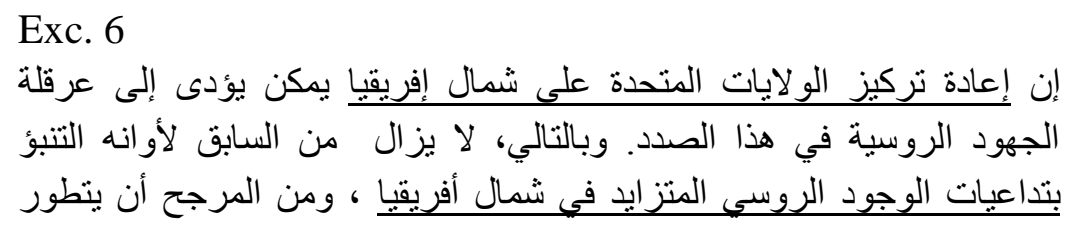

الوضع في عام 2019. (The Washington Institute, 2019)

The Washington Institute argues that 'الوجود الروسي المنزايد', i.e., 'rapidly increased Russian presence' in North Africa should be viewed as a serious warning of inevitable detrimental political and economic consequences in this region. There are two fallacious premises on which The Washington Institute (2019) bases the argument in this excerpt. The first false premise presented is that the Russian political and/or economic relations with the countries in North Africa must come from deeper undisclosed plans to use these countries in order to stand against the U.S. in this part of the world. 
Second, the U.S. has always retained the priority right to build up relations with the African states and be politically and militarily present in North Africa where the Russian are represented as intruders into this region. In consequence, The Washington Institute naturalizes the Russians as expansionists who take advantage of the North Africans which in turn reproduces the Russian role as intrinsically negative in this region. When deconstructed, fallacies nearly always exhibit an ideologized, yet embedded, polarization. It is Them, the Russians, whose political, economic, and military presence is destructive, while it is Us, the West/the U.S., who can and should stop them and bring law and order to North Africa.

\section{The Rhetorical Level}

\section{Euphemism}

Exc. 7

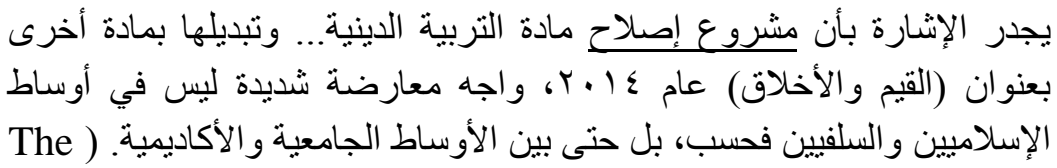

(Washington Institute, 2017

The Washington Institute (2017) develops a reporting narrative in which it introduces the term of 'مشروع إصلاح', i.e., 'a reform project' to replace the supposedly more terrorism-motivating Islamic education. In this excerpt, the strategy of euphemization produces a less controversial discourse while the term 'إصلاح', i.e. 'reform' leaves the recipients with the unavoidable impression that there indeed exists what needs to be reformed in the Islamic religious textbooks. Thus, the euphemized message re-emphasizes that textbooks about Islamic teachings must be abandoned and replaced by more tolerant educational content. While changing the title from 'التربية الدينية', i.e., 'religion education' to 'القيم والاخلاق', i.e., 'values and morals' may well refer to modifying and/or adding a particular religious content, it neither necessarily entails nor stipulates entirely replacing the content for the sake of ridding those textbooks from flawed or inappropriate Islamic teachings. This is where The Washington Institute (2017) endeavors to re-introduce Islam as an intrinsically intolerant faith towards other religions. 
Exc. 8

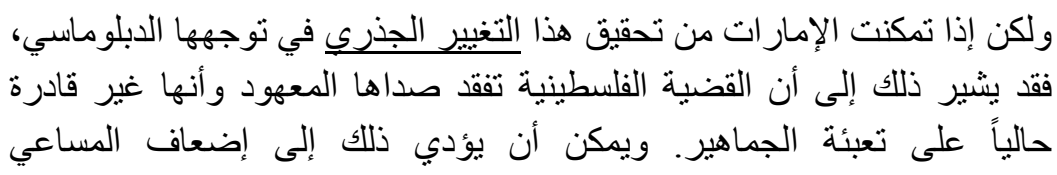

الدبلوماسية للفلسطينيين. (The Washington Institute, 2020)

The United Arab Emirates is about to achieve an unprecedented development in its foreign policy particularly with Israel (The Washington Institute, 2020). Adopting a euphemist approach to the political validity of the recent Abraham Accords is noticeable in the discourse of the Israeli-Palestinian conflict. The euphemized phrase in this excerpt is 'التغيير الجذري', i.e., 'the radical change'. If taken separately, The Washington Institute conveys that 'التغيير', i.e., 'change' is logical and is indeed a pressing departure from fighting for the exhausted Palestinian cause, while 'الجذري', 'radical' further modifies the first part by referring to the required quality of that 'change' to be that of a 'radical' type. That is, the strategy of euphemism in this excerpt calls for a more practical approach by those who oppose the Israelis so-called 'right to exist' towards the current reality in which the Israelis have an independent state in the Middle East. Another dimension of this euphemism, and the desired message to communicate, is the political re-classification of the Palestinian issue as one that has been vacuumed of its traditional momentum since, the Institute implies, influential Arab countries such as the UAE realizes that they have been defending a lost cause and it is now the time for such a تغيير الجذري'.

\section{Metaphor}

Exc. 9

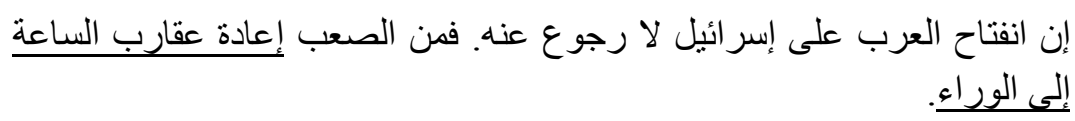

(The Washington Institute, 2020)

The metaphor of 'إعادة عقارب الساعة للور اء' i.e., 'turn back the clock' is of high rhetorical acceptance to make one's point quite valid towards matters that are presented as irrefutably undisputable. In order to validate the current sociopolitical situation of the Israeli-Palestinian conflict, The Washington Institute (2017) employs a metaphoric force to establish an analogical relation 
between (a) a universally valid metaphorized resemblance, i.e., the physical impossibility of going back in time in order to fix a particular situation, and (b) the existence of the state of Israel as an incontestable reality. Therefore, the process of metaphorization is intended to cognitively corner the recipients so they reduce the two facets of the analogy to each other and reconsider what has become the new normal, i.e., a hegemonized normalcy defended for the sake of legitimatizing the very existence of the state of Israel towards which the Arabs' 'إنفتاح' is reaffirmed as a fait accompli.

Exc. 10

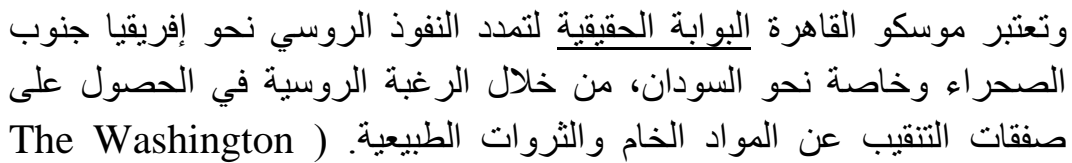

(Institute, 2019

The Russians look for a means through which they can seize South Africa's natural resources and Egypt seems to be fit to commence this task (The Washington Institute, 2019). In order to describe the Russian influence in North African in a negative light, the Washington Institute draws on the metaphor of Egypt being nothing but a 'gateway'. This is done to reflect the ill intentions of Russia of using the Egyptians to 'extend' Russia's power, i.e., likening Cairo to a 'بوابة', i.e., 'gate' is mentioned to re-emphasize that the Russians hold no honest interest in developing political or economic relations with Egypt other than exploiting it as a ploy to take over the naturally rich southern part of Africa. The metaphoric potential of 'البوابة', i.e., 'the gate' is intended to represent the Russians as opportunists who seek controlling this 'gateway' while allowing no other international powers to compete over North and South Africa. As resembling Cairo to a 'gateway' functions to divest Egypt of controlling their own political and economic interests, the Russian's presence in Africa is re-cast to be purely subversive and opportunistic.

\section{Hyperpole}

Exc. 11

$$
\begin{aligned}
& \text { فمن وجهة نظر القادة العرب ، دعت تللك الإدارة [الأمريكية] موجة الإسلام }
\end{aligned}
$$

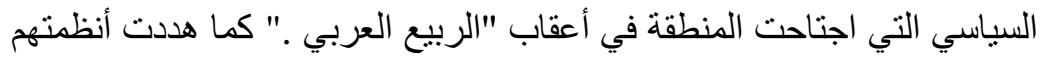




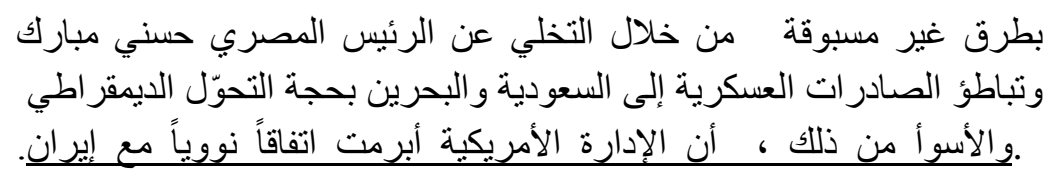

(The Washington Institute, 2017)

The Obama administration supported the 'موجة الاسلام السياسي', i.e., 'wave of political Islam' which paved the way for the so-called Arab Spring uprisings against 'القادة العرب', i.e., the 'Arab leaders' (The Washington Institute., 2017). In order to undermine the polices of the Obama administration in the Middle East, the Institute attempts to hold this administration responsible for striking a nuclear deal with Iran. The hyperbole of 'الأسوأ من ذللك', i.e., 'the worse than that' serves a twofold purpose, it offers (a) an exaggeration of the recklessness of the Democrats and thus a failure in dealing with Iran, and (b) a dangerous repercussion of allowing Iran to enjoy nuclear privileges. Utilizing this hyperbolic proposition, the Institute repackages these policies to foreground the political positive role of Israel that has always been against granting such power to Iran who may threaten its gulf neighbors. This is the deceptive threshold from which the Institute recasts Israel as an influential state that shares with the Arabs their fears which in turn characterizes the embedded message in this article: siding with Israel, i.e., full normalization, is the best solution for the Arab leaders if they seek prosperity and stability for their countries.

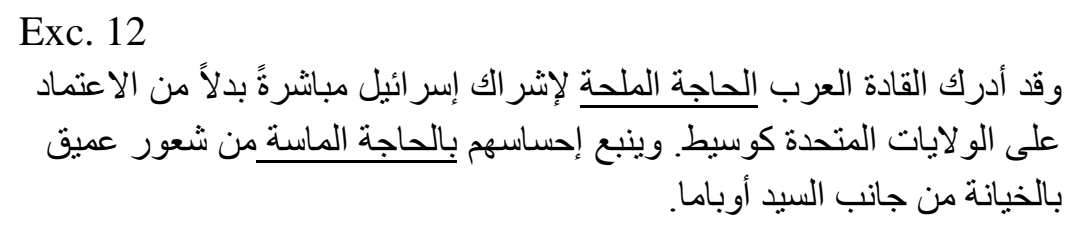

(The Washington Institute, 2017)

President Obama compromises the U.S. policies in the Middle East through 'الخيانة', i.e., 'treason' of the way the U.S. has always backed up its Mideastern allies (The Washington Institute, 2017). In this excerpt, the deceptive message is implicated with the Arab leaders, whose loyalty to the U.S. has not been respected, trying to look for better allies than the United States. The political despair of the Arabs is brought to surface via the hyperbole of 'الحاجة الملحة', i.e., 'the pressing need' and 'الحاجة الماسة', 'the dire 
need' to have a powerful ally. The Washington Institute (2017) defends a typical conservativism-motivated ideological narrative that implicitly condemns the Left-based policy of the Obama administration in the Middle East where the latter has abandoned the Arab leaders who now, the misleading message goes, seek finding a sincerer and more understanding political ally. In this exact political juncture, Israel is re-presented as the perfect match for this alliance and is re-introduced as a state that can bear the burden of being a regional powerful ally with an economic or political support ready to defend its friends and allies against their enemies.

\section{Conclusion}

In the light of the political topics under analysis, the argumentative and rhetorical deception strategies are found to be of moderate to high abundance. These strategies are a reflection of the considerable significance of deception in the discourse of the think tank of The Washington Institute. Taking into account the social and political contexts that contain the political topics concerned, The Washington Institute seeks an ideological reproduction of these topics in order to impose (a) a naturalized sociopolitical hegemony of e.g. Islam as the religion of terror, and (b) a state of two polarized parties, i.e., an ideological polarization in which the conservative U.S. is positioned against its enemies such as the Russians and Muslims. The above findings can be drawn on when textbooks in fields such as media, communication, political studies, and discourse analysis are developed. They may also help lay recipients to develop more practical critical thinking when dealing with discourses such as political speeches or elections campaigns, in addition to the rapidly evolving social media platforms.

\section{References}

Al-Hindawi, F., \& Al-Aadli, N. (2017). The Pragmatics of Deception in American Presidential Electoral Speeches. Canadian Center of Science and Education 5, 207-219. 
Bhatia, A. (2006). Critical Discourse Analysis of Political Press Conferences. Discourse and Society 17(2), 173-203.

Chilton, P. (2004). Analysing Political Discourse. London: Routledge.

Chouliaraki, L., Fairclough, N. (1999). Discourse in Late Modernity Rethinking Critical Discourse Analysis. Edinburgh: Edinburgh University Press.

Carter, E. 2014. Deception in different contexts. In T. R. Levine (Ed.), The Encyclopedia of Deception (pp. 264-268). Sage.

Dunmire, P. L. (2012). Political Discourse Analysis: Exploring the Language of Politics and the Politics of Language. Language and Linguistics Compass 6 (11), 735-751.

El-Zawawy, Ahmed, M. (2017). Towards a New Linguist Model for Detecting Political Lies. Russian Journal of Linguistics 21(1) 183-202. Fairclough, N. (1989). Language and Power. New York: Longman Inc. Fairclough, N. (1995). Critical discourse analysis: the critical study of language. New York: Longman Publishing.

Fairclough, N. (2012). Critical discourse analysis. In Gee, J. P. \& Handford, M. (Eds.), The Routledge Handbook of Discourse Analysis (pp. 9-20). New York: Routledge.

Fowler, R.G., Kress, G. R., Trew, A.A., Hodge, R.I.V. (1979) Language and Control. New York: Routledge and Kegan Paul.

Galasinski, D. (2000). The Language of Deception. London: Sage Publications.

Godson, R. and Wirtz, J. J. (2000). Strategic Denial and Deception. International Journal of Intelligence and Counter Intelligence, (13) 4, 424-437.

Gupta, S. (2014). Definitions of Deception. In Levine T R (Ed.) Encyclopedia of Deception $\quad$ (pp. 250-251). London: SAGE Publication

Macdonald, S. (2007). Propaganda and Information warfare in the twenty-first century. London: Routledge.

Mahon, J.E. (2014). Characteristics of Deception. In Levine, T. R. (Ed.) Encyclopedia of Deception (pp. 246-249). London: SAGE Publication. McGann, J. (2019). Think Tanks, Foreign Policy, and The Emerging Powers. Philadelphia: Palgrave Macmillan. 
Nate, R. (2006) Metaphor. In: Sloane, T. (ed) Encyclopedia of Rhetoric (pp. 511-514). London: Oxford University Press.

Olajimbiti, E. 2019. The Pragmatics of Political Deception on Facebook. In Chiluwa, I. \& Samoilenko, A. (eds.), Handbook of Research on Deception, Fake News, and Misinformation Online (pp. 308-325). IGI Global.

Oswald S, Maillat, D. and Saussure, L. (2016). Deceptive and uncooperative verbal communication. In: Rocci, A., Saussure, L. (eds) Verbal Communication (pp. 509- 534). Berlin, Boston: De Gruyter Mouton.

Paolucci, P. (2009). Public Discourse in an Age of Deception: Forging the Iraq War. Critical Sociology, 35(6) 863-886.

Plehwe, D., (2015). The politics of policy think-tanks: organizing expertise, legitimacy and counter-expertise in policy networks. In Fischer, F., Torgerson, D., Durnova, $\quad$ A., $\quad$ Orsini, $\quad$ M., (Eds.), Handbook of Critical Policy Studies (pp. 358-377). Cheltenham:

Edward Elgar.

Strudler, A. (2005). Deception Unraveled. Journal of Philosophy, 102 (9), 458-473.

Teubert W. (2010). Meaning, Discourse and Society. New York: Cambridge University Press.

Van Dijk T. A. (2015). Ideology. In Mazzoleni, G. (Ed.) The International Encyclopedia of Political Communication (pp. 495505). John Wiley \& Sons.

Van Dijk, T. A. (2000). Ideology and Discourse. (accessed September 20, 2020). http://www.discourses.org/download/books/.

Van Eemeren, F., Garseen, B., Meuffels, B. (2006). Fallacies and Judgments on Reasonableness. Springer.

Van 't Veer A. E. (2014). Attitudes towards Deception. In Levine T R (Ed.) Encyclopedia of Deception (pp. 244-246). London: Sage Publication.

Weaver R. K. (1989). The Changing World of Think Tanks. Political Science and Politics, Vol. 22, No. 3.

Wiarda, H. J. (2010). Think tanks and foreign policy: The Foreign Policy Research Institute and presidential politics. Plymouth: Lexington Books. 
Wodak, R. (1997). Critical discourse analysis and the study of doctorpatient interaction. In Gunnarsson, B.-L., Linell, P., and Nordberg, B. (Eds.), The Construction of Professional Discourse (pp. 173-200). London: Longman.

\begin{abstract}
About the author
Ali Al-juboori MA. Candidate is an M. A. candidate in the Department of English, College of Languages, University of Baghdad. His areas of interest are discourse analysis, psycholinguistics, and universal grammar.

Email: ali.hamza501@gmail.com
\end{abstract}

Supervisor Sabah S. Mustafa is a professor of Linguistics and Translation in the Department of English, University of Baghdad, College of Languages since 1987. He has published several articles in the area of Linguistics and Translation. His research interests are contrastive linguistics, syntax, semantics, pragmatics, and discourse analysis. He is currently Editor-in-chief of the Journal of Languages.

Email: sabahmustafa1956@gmail.com

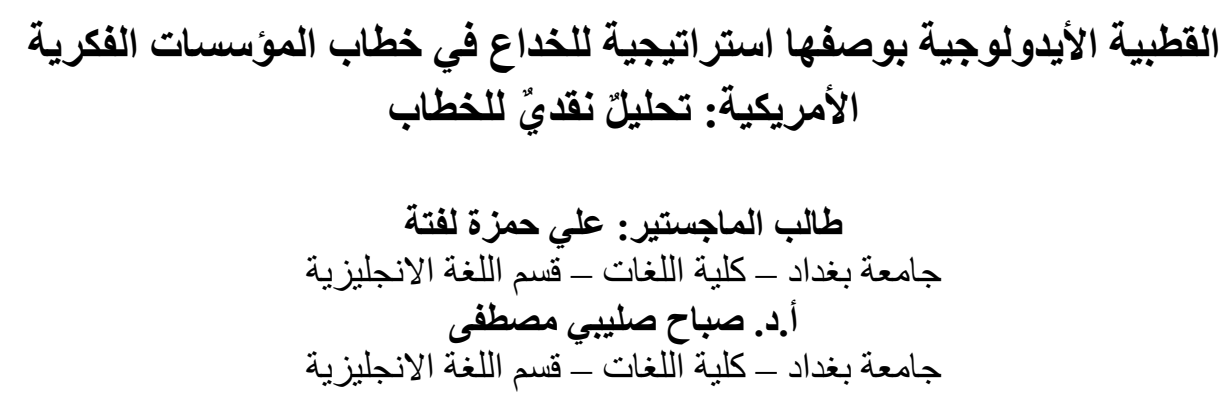

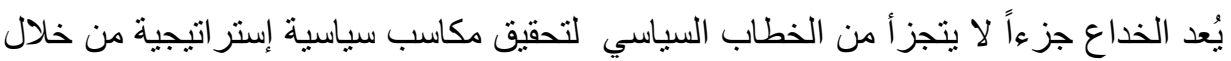

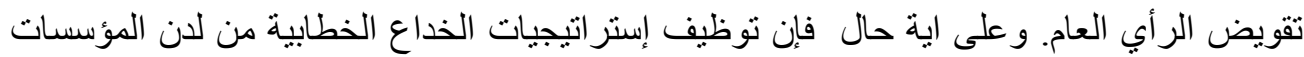




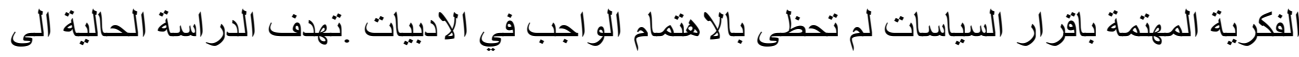

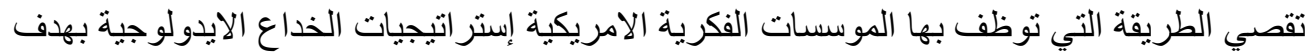

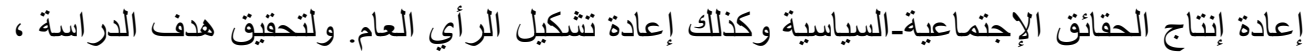
جرى تبني مفهوم القطبية الآيدلوجية (ideological polarization ) للعالم فان دايك (2000) الذي يثير الى تقديم الذات تقديماً ايجابيا وتقديم الاخرين تقديما سلبيا لاجر اء تحليل نقدي ل لاربعة

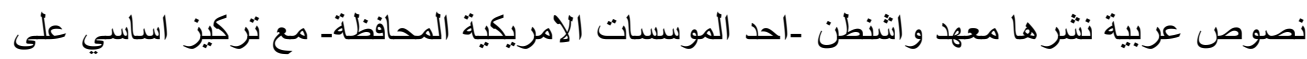
اربعة قضايا سياسية مختلفة. تُظهر النتائج الدور المحوري في توظيف إستر إستر اتيجيات الخداع في سبيل

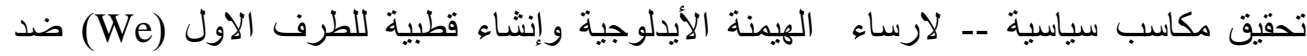
الطرف الثاني (Them).

الكلمات المفتاحية: تحليل الخطاب النقدي، الخداع، القطبية الآيدولوجية، الخطاب السياسي، المؤسسات الفكرية. 